\title{
Pengaruh Model Pembelajaran E-Learning Berbantuan Google Classroom dan Zoom Cloud Meeting Terhadap Hasil Belajar Siswa Di SMK Negeri 6 Samarinda
}

\author{
Nisa ${ }^{\text {a }, 1^{*} \text {, Laili Komariyah }}{ }^{\text {b, }}$, Muliati Syam ${ }^{\text {c, } 3}$ \\ a,b,cFakultas Keguruan dan Ilmu Pendidikan, Universitas Mulawarman, Jl. Kuaro Gunung Kelua, Samarinda, 75119 \\ 1nisatalwi@gmail.com*
}

\begin{abstract}
ABSTRAK
Pembelajaran fisika di sekolah menengah banyak menuntut siswa untuk lebih aktif belajar mandiri disamping pembelajaran yang dilakukan di kelas. Melalui e-learning berbantuan google classroom dan zoom sebagai pengganti sarana tatap muka, siswa dapat leluasa belajar secara mandiri dan melakukan diskusi dengan pengajar dimanapun dan kapanpun. Penelitian ini bertujuan untuk mengetahui respon siswa, hasil belajar siswa, dan pengaruh model pembelajaran terhadap hasil belajar siswa di SMK Negeri 6 Samarinda. Teknik pengambilan sampel dalam penelitian ini yaitu purposive sampling dengan sampel kelas $\mathrm{X}$ TKRO 2 sebanyak 30 siswa. Jenis penelitian yang digunakan adalah kuantitatif dengan one group pretest-posttest design. Pengambilan data menggunakan angket untuk mengetahui respon siswa terhadap model pembelajaran serta tes awal dan tes akhir untuk mengukur hasil belajar siswa. Analisis angket menunjukkan bahwa respon siswa termasuk dalam kategori baik. Analisis hasil belajar siswa menunjukkan bahwa kelas X TKRO 2 memperoleh $\mathrm{N}$-Gain sebesar 0,59 yang terkategori sedang dengan rata-rata nilai sebesar 70,20. Pengujian hipotesis dengan menggunakan uji-t berpasangan diperoleh nilai signifikan sebesar 0,000. Dengan demikian dapat disimpulkan bahwa terdapat pengaruh model e-learning berbantuan google classroom dan zoom terhadap hasil belajar siswa. Selain itu, pembelajaran $e$-learning ini sesuai digunakan untuk memfasilitasi kegiatan belajar siswa di masa pandemi.
\end{abstract}

Kata kunci : e-learning, google classroom, zoom cloud meeting, hasil belajar

\section{ABSTRACT}

Physics learning in high school requires students to be more active in self-learning in addition to learning in the classroom. Through e-learning model assisted by google classroom and zoom instead of face-to-face facilities, students can freely learn independently and have discussions with teachers anywhere and anytime. This study aims to find out the student's response, student learning outcomes, and the effect of the learning model on student learning outcomes at SMK Negeri 6 Samarinda. Sampling techniques in this study are purposive sampling with class X TKRO 2 samples as many as 30 students. The type of research used is quantitative with one group pretest-posttest design. Data collection uses questionnaires to determine students' responses to learning models as well as pretest and posttest to measure student learning outcomes. Analysis of the questionnaire showed that the student response belonged to a good category. Analysis of student learning outcomes showed that X TKRO 2 class received an N-Gain of 0.59 which was categorized as moderate with an average score of 70.20. Hypothetical testing using paired t-tests obtained a significant value of 0.000. So it can be concluded that there is an effect of e-learning model assisted by google classroom and zoom on student learning outcomes. In addition, e-learning is suitable to facilitate student learning activities during the pandemic.

Keyword: e-learning, google classroom, zoom cloud meeting, learning outcomes

\section{PENDAHULUAN}

Seiring dengan perkembangan zaman, teknologi yang ada selalu mengalami perkembangan setiap harinya. Dengan berkembangnya ilmu pengetahuan dan teknologi (IPTEK) yang semakin pesat, tentu meningkatkan kewaspadaan kita terhadap berbagai aspek. Tidak dapat dipungkiri bahwa perkembangan teknologi juga membawa pengaruh pada aspek pendidikan. Perkembangan teknologi sangat penting dalam bidang pendidikan untuk meningkatkan kualitas sumber daya manusia terutama dalam proses pembelajaran. Menurut Achyanadia (2016) teknologi pendidikan sebagai bidang kajian yang mengatasi permasalahan pendidikan dan pembelajaran secara tidak langsung memiliki peran yang cukup penting untuk ikut serta dalam menciptakan sumber daya yang berkualitas. Peranan teknologi pendidikan jangka panjang yakni mendidik para peserta didik sehingga menghasilkan caloncalon tenaga kerja sebagai sumber daya manusia berkualitas kelak kemudian hari (Wartomo, 2018).

Pembelajaran berbasis IPTEK akan mendukung semua materi pembelajaran siswa di sekolah terutama dalam bidang IPA. Dalam perspektif dunia pendidikan, fisika dipandang sebagai pelajaran yang sulit dan membosankan oleh sebagian besar siswa. Hal ini berpengaruh terhadap rendahnya 
pencapaian hasil belajar siswa pada mata pelajaran fisika. Hasil belajar yaitu perubahan-perubahan yang terjadi pada diri peserta didik, baik yang menyangkut ranah kognitif, afektif dan psikomotor sebagai hasil dari kegiatan belajar (Susanto, 2013). Secara umum ada dua faktor yang mempengaruhi dalam proses belajar siswa, yaitu faktor internal dan faktor eksternal. Faktor internal seperti faktor fisiologis (kesehatan tubuh), psikologis (minat, bakat, intelegensi, emosi, kelelahan, dan cara belajar). Sedangkan faktor eksternal seperti lingkungan dan instrumental seperti guru, kurikulum, model pembelajaran, serta media pembelajaran (Putri et al., 2016).

Pembelajaran yang umumnya diterapkan di sekolah yaitu pembelajaran konvensional yang melibatkan guru dan siswa berinteraksi secara langsung melalui pembelajaran tatap muka. Dalam pembelajaran ini guru berperan sebagai pengajar yang cenderung aktif sedangkan siswa hanyalah sebagai objek dalam pembelajaran. Pada umumnya pembelajaran tradisional menggunakan cara-cara sederhana dan relatif monoton setiap mengajar, yaitu dengan ceramah dan tanya jawab. Adanya keterbatasan waktu di kelas dimana siswa dan guru bertemu fisika hanya pada jam pelajaran berlangsung, menuntun guru memilih metode ceramah agar dapat menyelesaikan materi pelajaran dengan waktu yang terbatas. Hal ini menyebabkan pemahaman konsep siswa terhadap mata pelajaran fisika dianggap kurang. Penggunaan metode ceramah dalam pembelajaran secara terus menerus dapat menyebabkan kejenuhan dan kebosanan pada peserta didik, sehingga materi yang disampaikan guru tidak dapat diserap oleh peserta didik secara optimal (Pujiono, 2016).

Pembelajaran fisika di sekolah menengah banyak menuntut siswa untuk lebih aktif belajar mandiri disamping pembelajaran yang dilakukan di kelas. Oleh karena itu untuk menyesuaikan dengan perkembangan teknologi ditemukanlah model pembelajaran yang sesuai yaitu e-learning. Metode pembelajaran mengalami perkembangan menuju pembelajaran berbasis internet yang dinamakan electronic learning (e-learning). Model pembelajaran ini akan tetap bertahan meskipun teknologi semakin berkembang.

Pembelajaran yang diterapkan saat ini merupakan pembelajaran Jarak Jauh (PJJ) yang dikarenakan adanya Pembatasan Sosial Berskala Besar (PSBB). PSBB dilaksanakan karena mewabahnya Corona Virus Desease 2019 (COVID-19). Wabah ini terjadi dikarenakan infeksi virus corona jenis baru yang diawali di Negara China, tepatnya di Wuhan (Zhou et al., 2020). Saat ini COVID-19 sudah menyebar ke berbagai wilayah, termasuk berbagai kota di wilayah Indonesia. Adanya COVID-19 ini mengakibatkan berbagai situasi ekonomi dan sosial terganggu sehingga pemerintah menghimbau untuk melaksanakan PSBB. PSBB adalah kebijakan pemerintah pusat (bekerja sama dengan pemerintah daerah) dalam rangka mengatasi pandemi COVID-19 dengan cara membatasi kegiatan tertentu dalam suatu wilayah yang diduga terinfeksi. Larangan itu meliputi kegiatan belajar-mengajar (baik di sekolah maupun kampus), kegiatan keagamaan, resepsi pernikahan, konser, wisata, hingga penggunaan transportasi umum dan pribadi (Agustino, 2020).

Adanya situasi seperti inilah guru harus memilah strategi pembelajaran yang tepat karena akan berpengaruh terhadap hasil belajar siswa. E-learning merupakan model pembelajaran yang tepat untuk mengatasi pembelajaran di masa pandemi tanpa adanya pembelajaran tatap muka di sekolah. Menurut Silahuddin (2015), e-learning adalah proses pembelajaran melalui alat bantu elektronik yang tersambung dengan internet. Melalui e-learning, peserta didik dapat leluasa mempelajari materi pelajaran secara mandiri dan melakukan diskusi dengan pengajar dimanapun dan kapanpun. Beberapa kelebihan e-learning yaitu kegiatan pembelajaran yang dapat dilakukan di luar jam pelajaran dapat dikelola dan dikontrol dengan baik oleh pengajar, pengajar dapat menambahkan materi pengayaan melalui internet, dan peserta didik dapat saling berbagi file dengan peserta didik lain (Malalina, 2018).

Untuk menunjang pembelajaran e-learning digunakan media pembelajaran yang efektif berbasis teknologi yaitu google classroom. Google classroom adalah aplikasi yang dibuat oleh google yang bertujuan untuk membantu pendidik dan peserta didik untuk mengorganisasi kelas di dunia maya serta berkomunikasi dengan peserta didik tanpa harus terikat dengan jadwal di kelas. Selain itu, untuk 
memaksimalkan pembelajaran e-learning digunakan aplikasi berbasis teknologi berupa video conference yaitu zoom cloud meeting. Pembelajaran dengan video conference dapat menggantikan pembelajaran yang biasanya dilakukan dengan tatap muka di kelas menjadi kegiatan tatap muka secara virtual melalui bantuan aplikasi yang terkoneksi dengan jaringan internet. Pemanfaatan video conference dalam pembelajaran jarak jauh dapat membantu siswa dan guru tetap melakukan interaksi tatap muka meskipun tidak berdekatan.

Google classroom dan zoom dapat dengan mudah diakses melalui android. Pada saat ini, tidak heran jika setiap orang termasuk siswa menggunakan android (handphone) dalam berkomunikasi sehari-hari. Namun yang ada saat ini penggunaan android hanya sebagai sarana komunikasi maupun perangkat untuk bermain. Padahal android juga bisa dimanfaatkan sebagai alat dalam proses pembelajaran. Penggunaan google classroom dan zoom tidak perlu melakukan proses instalasi yang rumit, setelah melakukan setup account google, maka pengajar dan pelajar bisa menggunakan google classroom dan zoom dengan akun email google masing-masing. Adapun kelebihan google classroom menurut Jansen M (Iftakhar, 2016) antara lain mudah digunakan, menghemat waktu, berbasis cloud, fleksibel, gratis, dan ramah seluler (mobile). Sedangkan kelebihan zoom yaitu versi dasar dari perangkat lunak pertemuan berbasis cloud ini gratis, serta pengguna memiliki sejumlah alat yang berbeda untuk dipilih selama proses pembelajaran (Pratiwi \& Wahyuni, 2019).

Berdasarkan pemaparan latar belakang tersebut, peneliti menduga bahwa terdapat kecocokan model pembelajaran e-learning berbantuan google classroom dan zoom untuk membantu siswa memahami konsep lebih baik. Oleh karena itu, peneliti bermaksud untuk meneliti "Pengaruh Model Pembelajaran E-Learning Berbantuan Google Classroom dan Zoom Cloud Meeting Terhadap Hasil Belajar Siswa di SMK Negeri 6 Samarinda" pada materi Impuls dan Momentum. Dengan demikian diharapkan mempermudah serta meningkatkan pemahaman serta minat siswa dalam pembelajaran fisika, sehingga hasil belajar siswa dapat meningkat.

\section{METODE}

Jenis penelitian yang digunakan pada penelitian ini adalah penelitian kuantitatif dengan desain penelitian one group pretest-posttest design, dimana pada rancangan penelitian ini hanya terdapat satu kelas eksperimen yang diberikan pretest dan posttest kemudian dibandingkan keadaan sebelum dan sesudah diberi perlakuan berupa pembelajaran dengan model e-learning berbantuan google classroom dan zoom cloud meeting. Penelitian dilaksanakan di SMK Negeri 6 Samarinda bulan september 2020 pada tahun ajaran 2020/2021 semester gasal. Adapun sampel penelitian ini adalah kelas X TKRO 2 sebanyak 30 siswa yang diambil menggunakan teknik purposive sampling.

Teknik pengumpulan data dilakukan dengan cara pengisian angket (kuesioner) dan tes tertulis. Angket digunakan untuk mengetahui respon siswa terhadap model pembelajaran, lembaran angket berisi 20 pernyataan dengan menggunakan skala likert. Aspek yang diamati melalui angket respon siswa yaitu sikap siswa terhadap model pembelajaran, minat siswa terhadap model pembelajaran dan keterkaitan model pembelajaran terhadap pemahaman materi fisika siswa. Tes tertulis berupa pretest dan posttest digunakan untuk mengukur hasil belajar siswa. Soal tes tertulis berbentuk uraian (essay) berjumlah 10 soal dalam ranah kognitif C3 dan C4. Teknik analisis data angket respon siswa yaitu dengan menghitung skor perolehan siswa.

Data hasil belajar siswa dianalisis menggunakan rata-rata skor perolehan siswa dan perhitungan $\mathrm{N}$-Gain untuk mengetahui peningkatan pada pretest dan posttest. Pengujian hipotesis dilakukan untuk mengetahui ada tidaknya pengaruh model e-learning berbantuan google classroom dan terhadap hasil belajar siswa. Analisis pengaruh menggunakan uji-t berpasangan dengan uji prasyarat berupa uji normalitas yang dilakukan dengan bantuan software IBM SPSS Statistics 26.0 for Windows. 


\section{HASIL DAN PEMBAHASAN}

\section{Angket Respon Siswa}

Model e-learning berbantuan google classroom dan zoom cloud meeting diterapkan dalam pembelajaran fisika pada materi impuls dan momentum di SMK Negeri 6 Samarinda. Pembelajaran tersebut dilakukan sebanyak 4 kali pertemuan dengan total 12 jam pembelajaran (12x30 menit). Namun pembelajaran tidak dilaksanakan secara tatap muka, melainkan secara daring. Hal ini disebabkan karena adanya situasi darurat akibat pandemi covid-19 (coronavirus disease 2019), sehingga pembelajaran tatap muka tidak dapat dilakukan di sekolah dan seluruh pembelajaran dialihkan menjadi sistem online. Pada sampel kelas diberi perlakuan berupa pembelajaran dengan menggunakan model e-learning berbantuan google classroom dan zoom sebagai pengganti pembelajaran tatap muka di kelas atau sarana pembelajaran jarak jauh (PJJ). Meskipun tidak melakukan pembelajaran secara langsung di sekolah, pembelajaran tatap muka dapat dilakukan secara online. Dengan adanya situasi darurat seperti inilah e-learning dapat menjadi pilihan dalam proses pembelajaran.

Angket diberikan kepada siswa kelas X TKRO 2 pada akhir pembelajaran. Angket digunakan untuk mengetahui tentang respon siswa terhadap model e-learning berbantuan google classroom dan zoom cloud meeting. Respon siswa yang ingin diketahui meliputi aspek sikap siswa terhadap pembelajaran, minat siswa terhadap pembelajaran, serta keterkaitan model pembelajaran terhadap pemahaman materi fisika siswa. Hasil pengisian angket respon siswa dapat dilihat pada gambar 1.

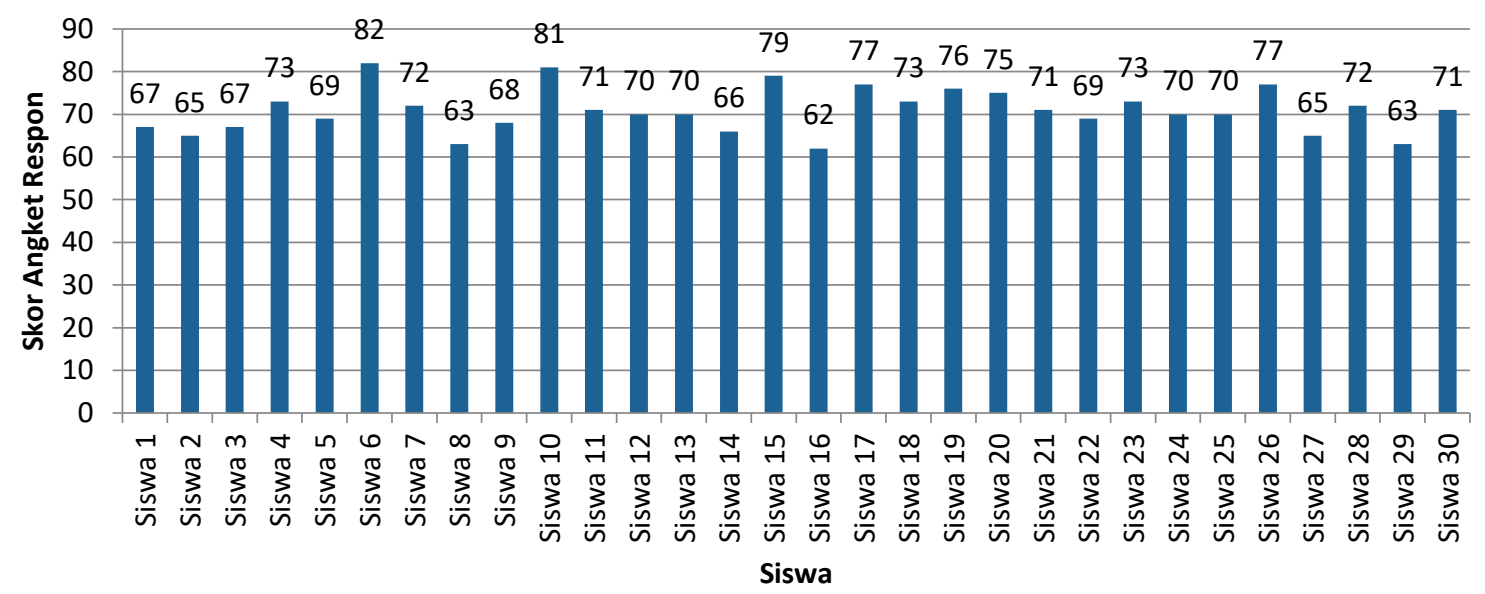

Gambar 1. Grafik Hasil Pengisian Angket Respon Siswa

Berdasarkan gambar 1 hasil angket respon siswa menunjukkan bahwa siswa memberikan tanggapan yang berbeda-beda yang dapat dilihat dengan perolehan skor angket yang diberikan siswa berada pada rentang skor 62 hingga 82 . Hasil skor tertinggi yang diperoleh dari angket respon siswa adalah 82. Hal ini menunjukkan siswa memiliki minat yang tinggi terhadap model pembelajaran dan dapat memahami materi fisika dengan baik melalui penggunaan model e-learning berbantuan google classroom dan zoom. Terdapat perbedaan yang cukup jauh antara skor tertinggi dan skor terendah hasil angket respon siswa. Skor terendah yang diperoleh salah satu siswa yaitu 62. Hal ini menunjukkan siswa memberikan respon yang kurang terhadap model pembelajaran. Siswa tersebut kurang maksimal dalam mengikuti pembelajaran dikarenakan sering terlambat memasuki ruang belajar zoom, sehingga tidak mengikuti materi pembelajaran dari awal.

Hasil analisis skor angket model e-learning berbantuan google classroom dan zoom yang disajikan dalam bentuk persentase dapat dilihat dalam tabel 1. 
Tabel 1. Persentase Respon Siswa Terhadap Model E-Learning

\begin{tabular}{cccc}
\hline Nilai & Kategori & Frekuensi & Persentase \\
\hline $20-29$ & Sangat Kurang & 0 & $0 \%$ \\
$30-49$ & Kurang & 0 & $0 \%$ \\
$50-69$ & Cukup & 12 & $40 \%$ \\
$70-89$ & Baik & 18 & $60 \%$ \\
$90-100$ & Sangat Baik & 0 & $0 \%$ \\
\hline
\end{tabular}

Berdasarkan tabel 1, analisis angket respon siswa berada pada kategori cukup hingga baik. Hal ini menunjukkan seluruh siswa memberikan respon yang baik terhadap model e-learning berbantuan google classroom dan zoom yang diterapkan pada materi impuls dan momentum. Hasil analisis skor angket berdasarkan aspek sikap terhadap pembelajaran, minat terhadap pembelajaran, dan pemahaman materi fisika siswa dapat disajikan dalam bentuk grafik, nilai rata-rata angket respon siswa untuk setiap aspek adalah sebagai berikut:

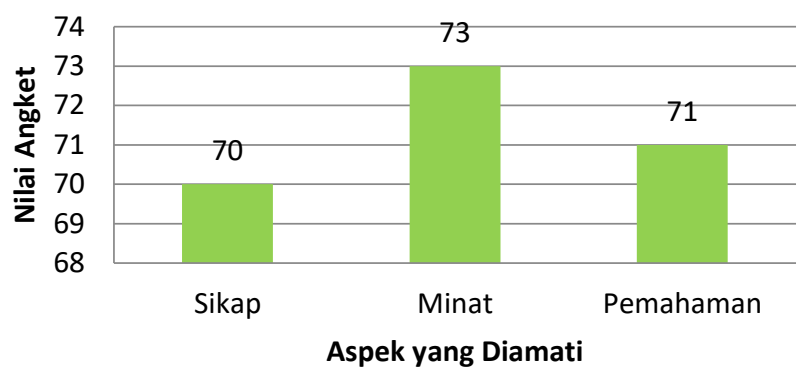

Gambar 2. Grafik Nilai Angket Berdasarkan Aspek yang Diamati

Berdasarkan gambar 2, menunjukkan ketiga aspek yang diamati termasuk dalam kategori baik. Hal ini sejalan dengan penelitian yang dilakukan oleh Budiman et al. (2019) bahwa siswa SMK di Pontianak memberikan respon yang baik terhadap media pembelajaran e-learning. Pada hasil analisis angket respon siswa diketahui bahwa siswa menunjukkan sikap yang baik terhadap proses pembelajaran e-learning berbantuan google classroom dan zoom. Meskipun tidak melakukan pembelajaran tatap muka di kelas, tetapi siswa tetap memperhatikan materi pembelajaran dengan baik melalui ruang belajar online yaitu zoom dan google classroom. Hasil angket menunjukkan rata-rata siswa memiliki minat yang tinggi terhadap pembelajaran. Siswa merasa antusias dan tertarik mempelajari materi impuls dan momentum selama proses pembelajaran. Hal tersebut terlihat pada sebanyak 73\% siswa tertarik dengan pembelajaran model e-learning berbantuan google classroom dan zoom. Pada saat proses pembelajaran siswa menunjukkan keaktifan dalam belajar. Siswa dapat berinteraksi dengan baik terhadap guru ataupun teman, serta aktif bertanya dan mengemukakan pendapat. Melalui pembelajaran e-learning berbantuan google classroom dan zoom, 67\% siswa merasa mudah memahami materi impuls dan momentum. Siswa dapat memahami materi dengan adanya penjelasan dari guru melalui pertemuan melalui zoom, serta bahan ajar dan latihan soal yang dibagikan melalui google classroom. Tidak hanya itu, siswa diberi kesempatan belajar mandiri dengan mencari dari berbagai sumber belajar offline maupun online.

\section{Hasil Belajar Siswa}

Pretest dan posttest dilaksanakan masing-masing selama 2 jam pembelajaran (80 menit), sedangkan total waktu untuk kegiatan belajar mengajar dilakukan selama 8 jam pembelajaran $(8 \times 40$ menit). Sebelum diberi perlakuan, peneliti terlebih dahulu melakukan pretest untuk mengukur kemampuan awal siswa sebelum diberi materi pembelajaran. Pemberian pretest dilakukan pada 2 jam pelajaran dari pertemuan pertama, sedangkan, pemberian posttest dilakukan pada 2 jam pelajaran dari pertemuan keempat. Tes yang diberikan berupa soal uraian (essay) berjumlah 10 soal dengan skor 
berbeda-beda untuk setiap soal yang disesuaikan dengan tingkat kesulitan soal. Pada kelas sampel diberi perlakuan berupa pembelajaran dengan menggunakan model e-learning berbantuan google classroom dan zoom. Hasil belajar siswa diukur kembali dengan memberikan posttest menggunakan instrumen tes yang sama. Secara keseluruhan jumlah siswa yang mengikuti pembelajaran dari pertemuan pertama hingga keempat adalah sebanyak 30 siswa. Sehingga jumlah data pretest dan posttest yang dianalisis dalam penelitian ini adalah 30 . Hasil pretest dan posttest siswa dapat dilihat pada gambar 3.

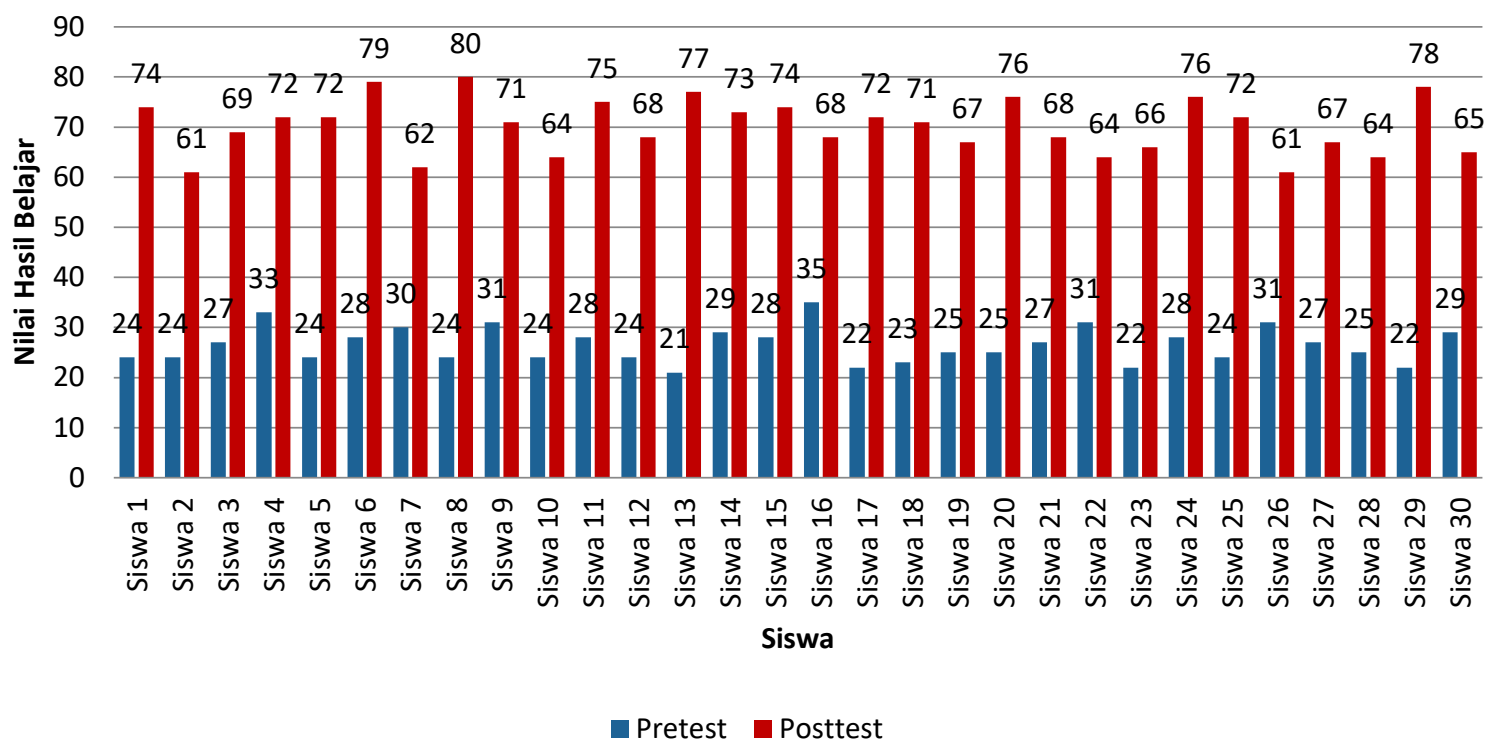

Gambar 3. Grafik Hasil Pretest dan Posttest

Berdasarkan gambar 3 hasil pretest pada kelas menunjukkan siswa mendapat nilai dari rentang 21-35. Setelah diterapkan model e-learning berbantuan google classroom dan zoom, hasil posttest pada kelas mengalami peningkatan dan siswa mendapat nilai dari rentang nilai 61-80. Data tersebut secara singkat disajikan pada tabel 2.

Tabel 2. Hasil Rata-rata Pretest dan Posttest

\begin{tabular}{lccccc}
\hline \multicolumn{7}{c}{ Descriptive Statistics } \\
\hline Hasil Belajar & N & Minimum & Maximum & Mean & Std. Deviation \\
\hline Pretest & 30 & 21 & 35 & 26,50 & 3.54 \\
\hline Posttest & 30 & 61 & 80 & 70,20 & 5,43 \\
\hline
\end{tabular}

Berdasarkan data hasil analisis pada tabel 2 menunjukkan bahwa ada peningkatan nilai rata-rata hasil belajar pretest dan posttest. Kelas mengalami peningkatan nilai rata-rata hasil belajar dari 26,50 menjadi 70,20. Pada tabel tersebut menunjukkan perbedaan nilai rata-rata hasil belajar posttest siswa lebih tinggi dibandingkan dengan hasil pretest siswa. Hal ini menunjukkan model pembelajaran $e$ learning berbantuan google classroom dan zoom memiliki dampak positif terhadap hasil belajar siswa. Pembelajaran dengan menggunakan model e-learning berbantuan google classroom yang disertai dengan aplikasi zoom sebagai sarana tatap muka online membuat siswa tetap aktif dan bersemangat dalam melaksanakan proses pembelajaran jarak jauh. Penerapan model $e$-learning dalam pembelajaran juga dapat berfungsi dengan baik untuk melatih siswa belajar mandiri dan memperoleh pengetahuan sendiri dari berbagai sumber. Pembelajaran ini mudah disesuaikan dengan waktu dan tempat, sehingga guru dan siswa dapat melakukan tanya jawab maupun diskusi dimana saja dan kapan saja selama daerah tersebut masih terdapat koneksi internet. Selain dapat meningkatkan hasil belajar siswa, e-learning juga merupakan alternatif pilihan model pembelajaran yang dapat memberikan solusi untuk pembelajaran jarak jauh yang diterapkan saat ini akibat mewabahnya covid-19. 
$\mathrm{N}$-Gain memberikan gambaran umum besarnya peningkatan hasil pretest dan hasil posttest siswa. Hasil analisis perolehan $N$-Gain terhadap hasil belajar siswa disajikan dalam tabel 4 .

Tabel 3. Perolehan nilai $N$-Gain

\begin{tabular}{cccc}
\hline Rata-rata Pretest & Rata-rata Posttest & $\boldsymbol{N}$-Gain & Kriteria \\
\hline 26,50 & 70,20 & 0,59 & Sedang \\
\hline
\end{tabular}

Kriteria peningkatan hasil belajar melalui pretest dan posttest dengan menggunakan analisis $\mathrm{N}$-Gain dapat diketahui perolehan nilai $N$-Gain untuk masing-masing siswa sesuai dengan kriteria tabel 4.

Tabel 4. Kriteria N-Gain Hasil Belajar Siswa

\begin{tabular}{cccc}
\hline Nilai $\boldsymbol{N}$-Gain & Kriteria & Frekuensi & Persentase \\
\hline $0,70 \leq \mathrm{g} \leq 1,00$ & Tinggi & 4 & $13 \%$ \\
$0,30 \leq \mathrm{g}<0,70$ & Sedang & 26 & $87 \%$ \\
$0,00 \leq \mathrm{g}<0,30$ & Rendah & 0 & $0 \%$ \\
\hline
\end{tabular}

Pada tabel 3 menunjukkan nilai $N$-Gain pada kelas sebesar 0,59 yang termasuk dalam kategori sedang. Hal ini sejalan dengan penelitian yang dilakukan oleh Rikizaputra \& Hanna Sulastri (2020) yang menunjukkan hasil belajar siswa menggunakan pembelajaran e-learning pada kelas XI MIA SMA Nurul Falah Pekanbaru memiliki nilai $N$-Gain sebesar 0,61 yang termasuk dalam kategori sedang. Berdasarkan data yang telah diperoleh, model e-learning berbantuan google classroom dan zoom dapat meningkatkan hasil belajar siswa. Namun peningkatan hasil belajar masih dalam kategori sedang. Pelaksanaan pembelajaran fisika pada kelas X TKRO 2 berlangsung pada jam terakhir. Hal ini menyebabkan siswa tidak fokus untuk menerima materi pembelajaran. Selain itu, terdapat beberapa siswa tidak memasuki ruang belajar online zoom tepat waktu sehingga siswa yang telah siap harus menunggu terlebih dahulu. Akibatnya jam pembelajaran pun menjadi mundur dan tidak mengikuti jadwal yang telah ditetapkan sebelumnya. Kendala lain yang timbul selama melakukan proses pembelajaran yaitu terdapat beberapa siswa yang mengirimkan tugas yang diberikan melalui whattsapp dikarenakan mengalami kesulitan dalam mengirimkan tugas melalui google classroom. Serta tidak semua daerah tempat tinggal siswa memiliki akses internet yang baik, sehingga koneksi internet yang buruk juga menjadi kendala siswa dalam mengikuti pembelajaran online.

Berdasarkan tabel 4, kriteria $\mathrm{N}$-gain untuk setiap siswa berada pada kategori sedang dan tinggi. Pada saat pembelajaran dengan model e-learning berbantuan google classroom dan zoom, siswa diberi kebebasan menemukan pengetahuannya sendiri. Hal ini juga dapat melatih siswa mandiri dalam belajar dan mandiri dalam mencari wawasan dari berbagai sumber baik offline maupun online. Pengetahuan yang ditemukan sendiri inilah yang akan mempengaruhi prestasi belajar yang diperoleh siswa menjadi lebih baik. Siswa akan lebih mengingat pengetahuan yang mereka peroleh sendiri.

Adanya hasil belajar yang kurang maksimal dari beberapa siswa disebabkan oleh beberapa faktor seperti akses internet dan pengontrolan dalam belajar. Pembelajaran dengan model e-learning membutuhkan akses internet yang baik untuk bisa menjalankan aplikasi google classroom, terutama aplikasi zoom yang membutuhkan kuota internet lebih besar. Oleh karena itu, siswa maupun guru harus mempunyai kuota internet yang memadai dan jaringan internet yang stabil. Selain itu, untuk pembelajaran tatap muka online melalui google classroom dan zoom masih dapat dikontrol guru. Tetapi kegiatan belajar mandiri siswa tidak sepenuhnya dapat dikontrol, sehingga hanya menekankan pada sikap jujur dan kemandirian siswa dalam belajar. Untuk mengatasi permasalahan ini dengan sistem pembelajaran jarak jauh yang sedang diterapkan saat ini, guru dapat melakukan berbagai upaya antara lain dengan memberikan dan mengarahkan siswa untuk mencari sumber belajar dari berbagai media di internet baik berupa website, youtube, dan lainnya. Selain itu, guru berusaha mengkoordinasi siswa lebih baik lagi dalam menemukan materi pada setiap pembelajaran. 
Pengujian hipotesis bertujuan untuk mengetahui ada tidaknya pengaruh e-learning berbantuan google classsroom dan zoom terhadap hasil belajar siswa. Hipotesis penelitian ini diuji dengan uji-t berpasangan. Sebelum melakukan uji $\mathrm{t}$ berpasangan terdapat uji prasyarat yaitu uji normalitas. Uji $\mathrm{t}$ berpasangan dan uji normalitas dianalisis dengan bantuan software IBM SPSS Statistics 26.0 for Windows. Uji normalitas yang digunakan adalah uji Shapiro Wilk. Data dapat dikategorikan terdistribusi dengan normal apabila nilai taraf signifikansinya lebih besar dari 0,05. Hasil uji normalitas data hasil belajar pretest dan posttest dapat disajikan dalam tabel 5.

Tabel 5. Hasil Uji Normalitas Data Hasil Belajar

\begin{tabular}{lccc}
\hline \multicolumn{4}{c}{ Test of Normality } \\
Shapiro-Wilk & \\
Hasil Belajar & Statistic & Df & Sig. \\
\hline Pretest & 0.948 & 30 & 0.152 \\
Posttest & 0.968 & 30 & 0.490 \\
\hline
\end{tabular}

Berdasarkan hasil pengujian pada tabel 5, hasil uji normalitas data hasil belajar pretest sebesar 0,152 dan hasil uji normalitas data hasil belajar posttest sebesar 0,490 sehingga dapat disimpulkan data hasil belajar pretest dan posttest yang diperoleh terdistribusi dengan normal.

Uji hipotesis yang dilakukan adalah menggunakan uji-t berpasangan karena data berdistribusi normal. Uji-t berpasangan digunakan untuk mengetahui apakah terdapat perbedaan yang siginifikan antara hasil belajar pretest dan posttest. Hasil uji-t berpasangan disajikan dalam tabel 6 berikut.

Tabel 6. Hasil Uji-T Berpasangan

\begin{tabular}{ccccccc}
\hline \multicolumn{7}{c}{$\begin{array}{c}\text { Paired Samples Test } \\
\text { Paired Differences }\end{array}$} \\
\hline & Mean & Std. Deviation & Std. Error Mean & T & df & Sig. (2-tailed) \\
\hline Pretest-Post1 & -43.700 & 7.159 & 1.307 & -33.434 & 29 & .000 \\
\hline
\end{tabular}

Hasil uji hipotesis berdasarkan tabel 6 diperoleh nilai signifikan 0.000 yang lebih kecil dari taraf signifikansi 0.05 . Kesimpulan yang diperoleh adalah hipotesis awal $\left(\mathrm{H}_{0}\right)$ ditolak dan hipotesis alternatif $\left(\mathrm{H}_{\mathrm{a}}\right)$ diterima. Sehingga diketahui terdapat perbedaan yang signifikan antara hasil belajar pretest dan posttest dengan perlakuan berupa penggunaan model e-learning berbantuan google classroom dan zoom cloud meeting pada materi impuls dan momentum. Hal ini sejalan dengan penelitian yang dilakukan oleh Aryaningrum (2016) yang menunjukkan adanya pengaruh positif penggunaan model e-learning terhadap hasil belajar peserta didik kelas XI SMA Negeri 9 Palembang, serta sejalan dengan penelitian yang dilakukan oleh Solikha \& Rasyida (2020) yang menunjukkan adanya pengaruh penggunaan metode e-learning berbasis schoology terhadap hasil belajar siswa kelas $\mathrm{X}$ IPS MAN Kota Pasuruan.

Penelitian yang telah dilakukan menunjukkan bahwa penggunaan model e-learning berbantuan google classroom dan zoom dapat meningkatkan hasil belajar siswa. Dengan adanya perbedaan yang signifikan pada hasil belajar pretest dan posttest siswa, maka dapat dikatakan bahwa terdapat pengaruh model e-learning berbantuan google classsroom dan zoom terhadap hasil belajar siswa. Pada pembelajaran menggunakan model e-learning, siswa diberi kebebasan untuk menemukan pengetahuannya sendiri serta diberi arahan untuk bisa belajar mandiri dengan baik. Pengetahuan yang ditemukan sendiri ini akan selalu dingat oleh siswa sehingga siswa tidak mudah lupa materi yang sudah dipelajarinya, serta siswa akan memperoleh hasil belajar yang lebih baik pula. 


\section{SIMPULAN}

Berdasarkan penelitian dan analisis data yang telah dilakukan di SMK Negeri 6 Samarinda kelas $\mathrm{X}$ TKRO 2 mengenai pelaksanaan model e-learning berbantuan google classroom dan zoom cloud meeting terhadap hasil belajar siswa pada materi impuls dan momentum, maka dapat ditarik kesimpulan bahwa respon siswa terhadap model e-learning berbantuan google classroom dan zoom cloud meeting di SMK Negeri 6 Samarinda termasuk dalam kategori baik. Untuk hasil belajar siswa di SMK Negeri 6 Samarinda pada materi impuls dan momentum dengan menggunakan model $e$ learning berbantuan google classroom dan zoom cloud meeting diperoleh rata-rata nilai sebesar 70,20. Terdapat perbedaan signifikan antara hasil belajar pretest dan posttest siswa yang artinya terdapat pengaruh model pembelajaran e-learning berbantuan google classroom dan zoom cloud meeting terhadap hasil belajar siswa pada materi impuls dan momentum di SMK Negeri 6 Samarinda. Hal ini didasarkan pada hasil perhitungan uji-t berpasangan yang memperoleh nilai signifikan 0,000 yang lebih kecil dari taraf signifikansi 0,05 .

Adapun saran yang dapat diberikan berdasarkan penelitian yang telah dilakukan yaitu hasil belajar siswa dapat ditingkatkan lagi dengan model e-learning berbantuan google classroom dan zoom cloud meeting jika melakukan pembelajaran tatap muka di kelas, tidak hanya melalui aplikasi zoom dan bila model ini diterapkan secara terus-menerus. Pemanfaatan model e-learning berbantuan google classroom dan zoom dapat dijadikan alternatif pilihan pada strategi pembelajaran fisika untuk meningkatkan hasil belajar siswa serta meningkatkan kemandirian belajar dan kemampuan siswa dalam memperoleh pengetahuan maupun informasi dari berbagai sumber. Selain itu, penggunaan model e-learning berbantuan google classroom dan zoom dapat diuji cobakan pada materi pelajaran lain dalam rangka meningkatkan hasil belajar siswa.

\section{REFERENSI}

Achyanadia, S. (2016). Peran Teknologi Pendidikan dalam Meningkatkan Kualitas SDM. Jurnal Teknologi Pendidikan, 5(1), 11-21.

Agustino, L. (2020). Analisis Kebijakan Penanganan Wabah Covid-19: Pengalaman Indonesia Analysis Of Covid-19 Outbreak Handling Policy: The Experience Of Indonesia. Junal Borneo Administrator, 16(2), 253-270.

Aryaningrum, K. (2016). Pengaruh Pembelajaran Berbasis Web (E-Learning) Terhadap Hasil Belajar Siswa Pada Mata Pelajaran Geografi Kelas Xi Di Sma Negeri 9 Palembang. Jurnal Penelitian Dalam Bidang Pendidikan Dan Pengajaran, 10(2), 154-162.

Budiman, A., Arifin, A., \& Marlianto, F. (2019). Pengembangan Media Pembelajaran Berbasis ELearning Pada SMK di Pontianak. Jurnal Nasional Komputasi Dan Teknologi Informasi (JNKTI), 2(2), 133-139.

Iftakhar, S. (2016). Google classroom: what works and how? Journal of Education and Social Sciences, 3, 12-18.

Malalina, R. F. Y. (2018). Pelatihan Google Classroom Untuk Mengoptimalisasi Proses Pembelajaran di FKIP Universitas Tamansiswa Palembang. Jurnal Cemerlang: Pengabdian Pada Masyarakat, 1(1), 58-70.

Pratiwi, A. D., \& Wahyuni, E. S. (2019). Potensi Aplikasi Zoom Cloud Meeting Dalam Pembelajaran Di Era Digital. Prosiding Seminar Nasional FKIP 2019, 1747-1754.

Pujiono. (2016). Pembelajaran CEM_Learning (C-Learning, E-Learning, M-Learning) Menuju Era Pembelajaran Digital. Prosiding Temu Ilmiah Nasional Guru, 1-9(November), 632-641.

Putri, D. I., Pratikto, H., \& Wardana, L. W. (2016). Pengembangan Media Autoplay untuk Meningkatkan Hasil Belajar Siswa pada Mata Pelajaran Prinsip-Prinsip Bisnis. Jurnal Pendidikan Bisnis Dan Manajemen, 2(2), 133-138.

Rikizaputra \& Hanna Sulastri. (2020). Pengaruh E-LEarning dengan Google Classroom Terhadap Hasil dan Motivasi Belajar Biologi Siswa. Lectura, Jurnal Pendidikan, 11(1), 106-118.

Silahuddin, S. (2015). Penerapan E-Learning dalam Inovasi Pendidikan. CIRCUIT: Jurnal Ilmiah Pendidikan Teknik Elektro, 1(1), 48-59. 
Solikha, N., \& Rasyida, I. (2020). Efektifitas Pembelajaran E-Learning Berbasis Schoology Terhadap Peningkatan Keaktifan Dan Hasil Belajar Siswa X IPS MAN Kota Pasuruan. Jurnal Ilmiah Edukasi \& Sosial, 11(1), 31-42.

Susanto, Ahmad. 2013. Teori Belajar \& Pembelajaran di Sekolah Dasar. Jakarta : Kencana Prenadamedia Group.

Wartomo. (2018). Peranan Teknologi Pendidikan Terhadap Peningkatan Kualitas Sumber Daya Manusia. Elementary School, 5(1), 112-119.

Zhou, G., Chen, S., \& Chen, Z. (2020). Back to the spring of 2020: facts and hope of COVID-19 outbreak. Frontiers of Medicine, 14(2), 113-116. 